\title{
New Geochemical Barrier to Detoxifyof Soil from Arsenic and Mercury
}

\author{
Anar Kolushpayeva and Amankul Akbassova
}

\begin{abstract}
This article researches the problem of the violation of ecological balance in the ecosystem that is noticed in the last century and caused by the wastes of a huge amount of pollutants from anthropogenic sources. This problem causes much worries of the entire humankind. The given article reveals a problem of weeding soil from heavy metals, in particular from arsenic and mercury. The results of the researches to detect chemical surface of sorbents and their colloid-chemical and absorption-structural, ionic exchange and complex building properties serve to explain the migration of substances and also for rational selection of natural sorbents at the time of their using in different nature protecting technologies. Authors got a new geochemical barrier, consisting of a mixture of the utilized bird's dung, a marble crumb and a peroxide of calciumwith the high absorbent activity. The research results allow to eliminate undesirable influence of heavy metals on plants and to get ecological clear products.
\end{abstract}

Index Terms-Geochemical barrier, peroxide of calcium, utilized bird's dung, detoxication.

\section{INTRODUCTION}

Soil system-is a dimensionless stable system of living and nonliving components, in which external and internal cycles of matter and energy are continuously committed. It is a sphere of human habitation with all its social, spiritual and economic-economic activities.

This non-renewable, irreplaceable strategic natural resource is one of the main national wealth of any country. It is the basis of agricultural production, the main source of food. Apart from agricultural soil functions are performed by a number of environmental to ensure the stability of the biosphere and possible existence of life on the Earth. At the heart of the agricultural, environmental and other soil functions is its most important property - is fertility.

Under fertility of the soil to provide ability to understand plant energy and nutrients for the synthesis of organic matter, i.e., it is an integral indicator of the value of crop.

There distinguished a natural fertility, determinants of the genesis and artificial fertility, main factors which are nutrients (macro and micronutrients), energy (light, heat, etc.), $\mathrm{pH}$, physical and chemical, biological and other processes, as well as their regimes, soil properties and states.

For macronutrients required for plant growth than

Manuscript received September 23, 2014; revised March 15, 2015.

Anar Kolushpayeva is with Almaty Management University, Kazakhstan (e-mail: rana_2302@mail.ru).

Amankul Akbassova is with H. A. Yassawe International KazakhTurkish University, Kazakhstan (e-mail: ecolog_kz@mail.ru). carbon, oxygen and hydrogen are the following seven elements-nitrogen, phosphorus, potassium, calcium, magnesium, sulfur and iron. Plants require further apart macro-cells following microelements-manganese, boron, molybdenum, copper, zinc, cobalt, iodine, and others [1][5]. If the content of macro-elements in plants varies from a few hundredths of a percent to a few percent by weight of the dry weight, the required content of trace elements-from thousandth to one hundred thousandth of a percent. Besides macro-and micronutrients, i.e. mineral elements to obtain a high yield of many plants are also necessary ultra-trace (rubidium, cesium, selenium, cadmium, silver, gold, mercury, etc.) in quantities not exceeding 10-6\% [6]-[10].

Soil is a natural resource that is overexploited and polluted. In connection with this area of fertile land is dramatically reducing.

The negative impact of hazardous substances on objects of biogeocenoses appears in different ways, especially with respect to the soil, which is the main component and the foundation of operation of all terrestrial ecosystems.

Every year there is an increase of the intensity of soil environment pollution by heavy metals, so the search and development of effective environmental and economic methods of providing access to clean crop production is a challenge for the agricultural sector. Clarification of the laws governing the status and behavior of toxicants in the objects of the biosphere is one of the crucial and urgent scientific problems in the general problem of environmental protection. Migration of toxicants in the environment is defined by the set of processes among which adsorption plays a major role. Finding patterns of migration, accumulation, transformation and translocation of contaminants in the soil-plant is fundamental since the mechanism of the processes can be controlled by the behavior of toxic substances in specific environments which are established on their basis having created a safe and optimal conditions for the development of plants and plant communities that is an essential condition of life support of representatives of all the families of living organisms.

The certain scientific and practical interest about the solution to this issue is the creation of geochemical barriers in the soil system to inhibit the translocation of heavy metals in plants.

It is known that the toxic components are adsorbed by organic substances and many mineral components of soils, as a result there is a change in the level of their toxicity and bioavailability. Manifestation of the adverse effects of polluting substances in agroeco-system depends on the solubility of the pollutants, their mobility in soil and species characteristics of crops. 
Analyzing data from the literature [11]-[14] and the results of our experiments [15]-[18] to study the sorption capacity of different materials for the management of migration, the translocation of $\mathrm{As}$ and $\mathrm{Hg}$ we have selected the geochemical barrier consisting of a mixture of recycled bird droppings, marble chips and calcium peroxide, which have high sorption.

\section{METHOD}

Calcium peroxide is a well-known commercial product which is manufactured on an industrial scale. It is widely used. The main decomposition products are hydrogen peroxide, oxygen, and thus it is used for bleaching, eliminating bad smells, as a local disinfectant. It is also known the use of calcium peroxide for agriculture to improve the growth of various crops at the expense of aeration as a result of the collapse of hydrogen peroxide to oxygen. When you add hydrogen peroxide it accelerates the process of decay. In addition the introduction of calcium peroxide into the soil makes it possible to adjust the $\mathrm{pH}$ value in the ecosystem due to the formation of $\mathrm{Ca}(\mathrm{OH})_{2}$.

The use of calcium carbonate and hydrogen peroxide, bird droppings reduce significantly the flow of heavy metals into plants due to their adsorption properties.

Fig. 1 shows the experimentally obtained data describing sorption processes which take place with the participation of the components.

As it is seen from Fig. 1, a mixture of calcium carbonate and hydrogen peroxide in the ratio of $4: 1$, respectively has the best adsorption capacity with respect to mercury. The same sorbent ratio was also the best during the sorption processes with arsenic. In this regard, further research is taken as a basis for our present composition of sorbents. On the basis of experimental studies it is also found that the balance in the system occurs within 10-20 minutes and it is a good indicator for operating conditions.

Fairly steep rise in the adsorption isotherms of both arsenic and mercury indicates free inner and outer surfaces of sorbents the sorbents to bind heavy metals. A mixture of carbonate and hydrogen peroxide has a high adsorption capacity with respect to arsenic and mercury.

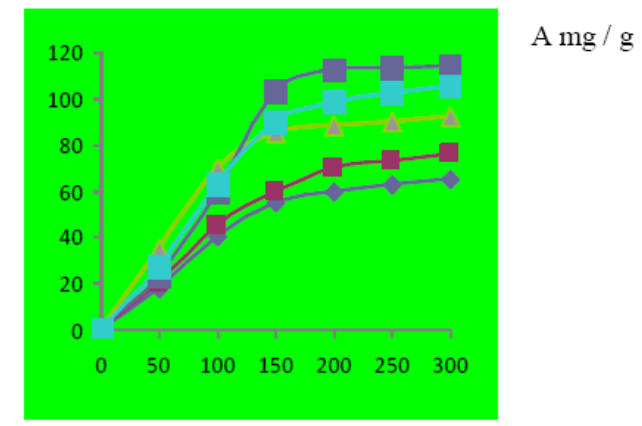

$\mathrm{CaCO} 3: \mathrm{CaO} 2$ 1) $1: 4$; 2) $1: 3$; 3) $1: 2$; 4) $4: 1$; 5) $5: 1$ Fig. 1. Adsorption of mercury isotherm with a mixture of calcium carbonate and hydrogen peroxide at different ratios of components.

Fig. 2 presents data on the basis of these results, by which we can judge about the dependence of sorption processes on the $\mathrm{pH}$ of theenvironment from which the heavy metals are extracted. The data obtained are consistent and understandable in the light of the forms of arsenic and mercury in aquatic systems as a function of $\mathrm{pH}$. Thus, with increasing of $\mathrm{pH}$ from 4 to 7 the intake of mercury in the plant is reduced by five times. The reason may lie in the formation of carbonate sediment, or the accumulation of hydroxo complexes $\mathrm{HgOH}^{+}$and $\mathrm{Hg}(\mathrm{OH})_{2}$ in the solution, or in the decrease in the activity of free $\mathrm{Hg}^{2+}$ ions due to their partial binding of ion pairs.

a)

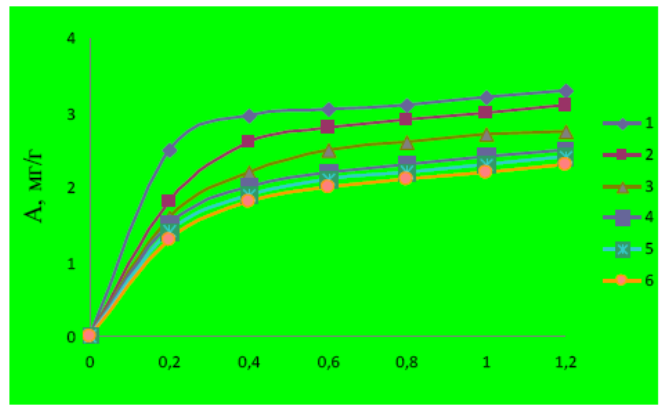

b)

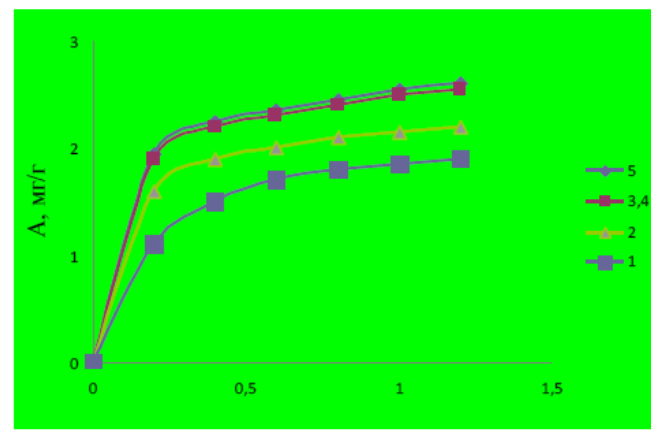

The pH value, s: 1 - 0 2-1.5-4.0; 3 - 6,8-8,0 4 - 8.0-10.0 5-10, 0-12,0 6- 13, 0

Fig. 2. Adsorption isotherms of mercury (a) and arsenic (b) with a mixture of calcium carbonate and hydrogen peroxide (4:1) at different values of $\mathrm{pH}$

The sorption of arsenic decreases rapidly with decreasing acidity of the solution, which is associated with a form of existence of this element in the anionic form. Besides, the change in $\mathrm{pH}$ has an effect on the cation exchange capacity of the adsorption complexes, which occur when using a mixture of poultry manure, calcium carbonate and hydrogen peroxide (Table I).

Given the above identified laws to inhibit the migration of arsenic and mercury in plants, along with calcium carbonate and peroxide, studies of adsorption processes with the additional introduction of a system of soil bird droppingswere carried out. For this purpose, the mixture of these three components was introduced into the soil and the extraction from ammonium acetate-buffered saline with $\mathrm{pH}$ $=4.8$ was carried out in 3 days.

To assess the migratory ability of arsenic and mercury in the soil system by introducing a mixture of poultry manure, calcium carbonate and hydrogen peroxide $(4: 1: 0,1)$ the rate of immobilization is applied. To calculate this ratio we used the following formula:

$$
K_{\text {imm. }}=[(C-C c) / C] \times 100 \%
$$

where $C$ is concentration of mobile forms of heavy metals in the soil prior to the introduction of sorbents;

$C c$ is the concentration of mobile forms of heavy metals in the soil after application of sorbents. 
TABLE I: VALUE OF A CATION EXCHANGE CAPACITY OF ADSORPTION COMPLEXES OF ORGANIC COMPOUNDS AND METALS, WITH APPLICATION TO THE SoIl the Mixture of Poultry Manure, Carbonate and Hydrogen PeroXide Calcium MG-EKV/100 Gram OF SoIl (Gray SoIL)

\begin{tabular}{|c|c|c|c|}
\hline \multirow{2}{*}{ object } & \multicolumn{3}{|c|}{ Cation exchange capacityat different $\mathrm{pH}$ values } \\
\cline { 2 - 4 } & 4,5 & 7,0 & 8,3 \\
\hline Soil $+\mathrm{CaCO}_{3}$ & 81,2 & 90,4 & 102,3 \\
\hline $\mathrm{Soil}+\mathrm{CaCO}_{3}+\mathrm{CaO}_{2}$ & 82,8 & 93,5 & 112,6 \\
\hline Soil $+\mathrm{CaCO}_{3}+\mathrm{CaO}_{2}+$ bird droppings & 118,7 & 130,0 & 148,4 \\
\hline
\end{tabular}

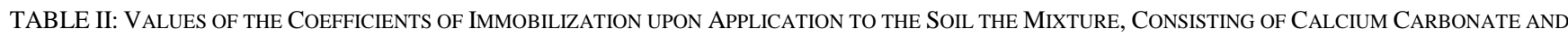
HYDROGEN PEROXIDE, AS WELl AS RECYCLED BIRD DROPPINGS IN THEIR MASS RATIO (4:1:0,1)

\begin{tabular}{|c|c|c|c|}
\hline \multirow{2}{*}{ Soil } & \multirow{2}{*}{ Soilsorbents } & \multicolumn{2}{|c|}{ immobilization ratio of heavy metal,\% } \\
\cline { 2 - 4 } & & $\mathrm{As}$ & $\mathrm{Hg}$ \\
\hline Greysoil & $\mathrm{CaCO}_{3}$ & 82 & 72 \\
\hline Greysoil & $\mathrm{CaO}_{2}$ & 70 & 81 \\
\hline Greysoil & $\mathrm{CaCO}_{3}+\mathrm{CaO}_{2}+$ birddroppings & 96 & 93 \\
\hline Blackearth & $\mathrm{CaCO}_{3}$ & 95 & 98 \\
\hline Blackearth & $\mathrm{CaO}_{2}$ & 93 & 95 \\
\hline Blackearth & $\mathrm{CaCO}_{3}+\mathrm{CaO}_{2}+$ birddroppings & 100 & 100 \\
\hline
\end{tabular}

TABLE III: CONTENT OF AS AND HG IN SOILS AND PLANTS WiTHOUT AND with THE INTRODUCTION OF THE SORPTION MiXTURE-BIRD DROPPINGS, CACO 3 , $\mathrm{CAO}_{2}, \mathrm{MG} / \mathrm{KG}$

\begin{tabular}{|c|c|c|c|c|c|c|}
\hline \multirow{3}{*}{ Object } & \multicolumn{4}{|c|}{ Withoutintroduction of sorbents } & \multirow{2}{*}{\multicolumn{2}{|c|}{$\begin{array}{l}\text { With the introduction of mixture of } \\
\text { sorbents in the plants of As and } \mathrm{Hg}\end{array}$}} \\
\hline & \multicolumn{2}{|c|}{ In the soils As and $\mathrm{Hg}$} & \multicolumn{2}{|c|}{ In plants $\mathrm{As}$ and $\mathrm{Hg}$} & & \\
\hline & Greysoil & Greysoil & Greysoil & Greysoil & Greysoil & Greysoil \\
\hline \multicolumn{7}{|c|}{ Arsenic } \\
\hline corn & 156,2 & 160,5 & 80,4 & 15,3 & 0.08 & 0,04 \\
\hline mustard & 156,2 & 160,5 & 91,4 & 22,7 & 0,09 & 0,3 \\
\hline clover & 156,2 & 160,5 & 75,6 & 14.2 & 1,8 & notdetected \\
\hline \multicolumn{7}{|c|}{ Mercury } \\
\hline Corn & 120,4 & 125,9 & 91,3 & 9,9 & 0,02 & notdetected \\
\hline Mustard & 120,4 & 125,9 & 111,0 & 98,0 & 0,08 & notdetected \\
\hline Clover & 120,4 & 125,9 & 70,3 & 60,6 & 1,3 & 0,01 \\
\hline
\end{tabular}

Tables II and III showed the calculated values of the coefficients of immobilization and experimental data characterizing the process of translocation of heavy metals in the presence of a soil system of an artificial geochemical barriers.

As it can be seen from the data when introducing of calcium compounds together with bird droppings, which contain various organic compounds, immobilization ratio increases (Table II). In the presence of calcium carbonate and hydrogen peroxide, arsenic and mercury compounds are converted into particles of insoluble form and accumulated in the solid phase of soil system. Increase in the immobilization in the presence of bird droppings can be explained by the formation of complex compounds of humic acids, which they contain, with metals. Metals may be included both in anionic and cationic moiety in humic acid. Carboxyl and phenolic hydroxy groupsare responsible for the formation of stable complexes with metal ions. Humic acid, having a high sorption capacity with respect to heavy metal ions behave as complexing sorbents. In addition, the heavy metals with a variable valence are able to interact with the $\mathrm{N}$-and S-containing functional groups of organic compounds. This gives a basis to determine the role of poultry manure as a powerful geochemical barrier responsible for the concentration of metals in soils. This accumulation cannot be considered definitive, since under the influence of various anthropogenic factors the metals can move into mobile and immobile form.

These obtained experimental dependences can be taken as the theoretical basis for the selection of sorption processes to develop a series of environmental measures.

As it follows from the experimental data presented in Table III, the number of heavy metals arriving at plants to create geochemical barrier does not exceed regulatory levels (Hg-0,5 mg / kg, As-0,3 mg / kg in food). The presence of peroxide calcium in geochemical barrier not only helps to detoxify the soil from heavy metals and to detoxify the bacterial, fungal, parasitic and viral microorganisms.

\section{CONCLUSION}

Thus, the introduction of arsenic and mercury contaminated soil mixture of poultry manure, calcium carbonate and hydrogen peroxide can eliminate the undesirable effects of heavy metals on the plants and grow the environmentally friendly products.

\section{REFERENCES}

[1] M. Panov, Chemical Technology, Semipalatinsk, 2002, p. 852. 
[2] A. Akbasov, G. Sainova, and A. Akbasova, Soil Science, Almaty: Bastau, 2006, p. 170.

[3] P. S. Hopkin, Ecophysiology of Metals in Terrestrial Invertebrates, Elsevier, Applied Science Publishers Ltd., 1989, p. 366.

[4] R. O. Butovsky, "Heavy metals such as fabricated chemical contaminants and their toxicity to soil invertebrate animals," Agrochemistry, no. 4, pp. 73-91, 2005.

[5] O. Eremin, E. I. Bakanova, and R. O. Butovsky, "Comparative activity of enzymes arthropods and worms due to pollution by heavy metals," Agrochemistry, no. 5, pp. 91-95, 1998.

[6] D. C. Adriano, Trace Elements in the Terrestrial Environment, N.Y.: Springer-Verlag, 1986, p. 167.

[7] A. M. Balsberg-Pahlsson, "Toxicity of heavy metals $(\mathrm{Zn}, \mathrm{Cu}, \mathrm{Cd}, \mathrm{Pb})$ to vascular plants, F literature review," Water. Fir Soil Pollut., vol. 47 , pp. 287-319, 1989.

[8] G. H. Schmidt, N. M. Ibrahim, and M. D. Abdallah, "Toxicological studies on the Iong-term effects of heavy metals $(\mathrm{Hg}, \mathrm{Cd}, \mathrm{Pb})$ in soil on the development of Aiolopus thalassinus (Fabr.) (Saltatoria: Acrididae)," Sci. Total Environ., vol. 107, pp. 109-133, 1991.

[9] F. T. Bingham, M. Costa, and E. Eichenberger, Some Questions Toxicity of Metal Ions, Moscow: Mir, 1993, p. 368.

[10] A. I. Perelman, E. N. Borisenko, N. F. Myrlyan, and M. P. Tentyukov, "Technogenic geochemical barriers," Geochemistry Industrial Processes, Moscow: Nauka, pp. 14-26, 1990.

[11] A. D. Akbassova, M. S. Duambekov, and G. A. Sainova, Protection of Soils, Astana: Fiolanta, 2008, p. 296.

[12] A. D. Akbassova, Z. T. Uisimbayeva, and G. A. Sainova, "Geochemical barriers to control the migration of arsenic and mercury in the objects of the environmental," Monograph. Taraz, pp. $108,2011$.

[13] A. D. Akbassova, A. T. Kolushpayeva, and Z. T. Uisimbayeva, "Cleaning soil from heavy metals by Indian mustard," in Proc. $3 r d$ International Scientific and Practical Conference, Universities and Society, 2010, pp. 234-237.

[14] D. Sunakbayeva, A. D. Akbassova, A. T. Kolushpayeva, and G. Sultanova, "The research of the biological activity of the mixture of bentonite clay and 1-methyl-4-(2-tiopikolinamino) piperidine," in Proc. International Scientific and Practical Conference, Modern Problems of Innovative Technologies in Education and Science, Shymkent, 2009.

[15] P. Waterman and S. Mole, Analysis of Phenolic Plant Metabolites, Oxford, 1994, p. 248

[16] Y. I. Tarasevich and F. D. Ovcharenko, Adsorption on Clay Minerals, Kiev: NaukovaDumka, 1975, pp. 340-345.

[17] A. V. Artemov, T. A. Tripoli, I. V. Pokhabov, and P. V. Prikhodchenko, "Calcium peroxide-A promising commercial product," Rus. Chemical Journal, vol. 2, pp. 136-139, 2008

[18] K. O. Kozhamberdiev, G. A. Sainova, and A. D. Akbasova, "Application of humate-carbonate-bentonite mixture to inhibit the translocation of heavy metals," Journal of Agricultural Sciences, Almaty, vol. 6, pp. 55-60, 2007.

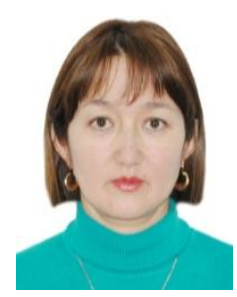

Anar Kolushpayeva was born on February 23, 1971. In 1993 she graduated from Kirov Kazakh State University, Department of Chemistry, Almaty, Kazakhstan. In 1996 she received the $\mathrm{PhD}$ degree in organic chemistry from Al-Farabi National University, Almaty, Kazakhstan. In 2006 she became a doctor of technical sciences from Tynyshpayev Kazakh Academy of Transportation and Communication, Almaty, Kazakhstan. Additionally she has attended several seminars: 1. UNESCO Seminar on communication skills, climate changing held IN June 2006, Almaty; 2. Seminar on chemical science integration with industry by the help of innovations held In May 2011, Almaty; 3. International Teachers Summer Session held in May 2011, Almaty. She had a training in Malaysian Culture and Education Study Center, Taylor's University, Malaysia University of California in 2011. Then in 2013 she had a long-term internship in Berkeley, Haas School of Business.

She started to work in 1999 as a lecturer at the Department of Marketing in Al-Farabi Kazakh National University. At the same time she was a junior scientist in the Institute of New Technologies and Chemical materials. In 2000 she began to work as an associate professor at the Department of Chemistry and Materials study in Tynyshpayev Kazakh Academy of Transportation and Communication. Since 2006 she is working as the head of the Department of General education disciplines in Almaty Management University. She wrote about 80 publications. Her research interests are mainly in environmental studies, green economy and agro-culture. She has conducted her own training on Environmental Pollution: reasons and consequences in 2010.

She is the author of 5 pre-patents of Kazakhstan for invention on methods of growth-stimulation and growth-regulation substances obtainment that is a new method of substance obtainment. In 2011 she was awarded with a grant for a project on development and technologies of new biologically active substances from metallurgical and oil waste by the Ministry of Education and Science of Kazakhstan.

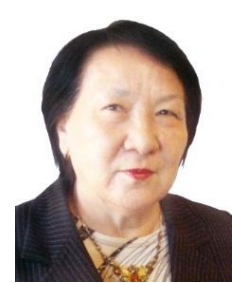

Amankul Akbassova is a doctor of technical sciences, a professor and the director of Scientific and Research Institute at International KazakhTurkish University named HA Yasavi. Akbassova was born in 1944. She graduated from Chemical Faculty of the Kazakh State University in 1961. Her research interests are in environmental issues and synthesis of new drugs based on industrial wastes. 